\title{
ANALYSIS ABOUT POLITENESS IN "BARBIE AS THE PRINCESS AND THE PAUPER MOVIE"
}

\author{
Viren Aulia Angginie ${ }^{1}$, Tika Santika ${ }^{2}$, Ula Nisa El Fauziah ${ }^{3}$ \\ ${ }^{1}$ IKIP Siliwangi \\ ${ }^{2}$ IKIP Siliwangi \\ ${ }^{3}$ IKIP Siliwangi \\ 11 viren.aulia@ gmail.com, ${ }^{2}$ tikasantika96@gmail.com, ${ }^{3}$ ulanefauziah@gmail.com
}

\begin{abstract}
Pragmatics aims to give an overview of the politeness principles, to describe and to explain the types and functions of Face Threatening Act (FTA) and Face Saving Act (FSA) use in relation with politeness in the conversation by the characters in Barbie as The Princess and The Pauper movie. The oral utterances are analyzed and interpreted descriptively based on Brown and Levinson's Face Threatening Acts theory and George Yule's theory. This research employs descriptive qualitative method and supported by percentage calculation. To collect the data, the researchers use some steps; collecting the conversation by watching it and listening the conversations carefully, use fields note. Finally, the result of the research shows there are two kinds of FTA and FSA that used by the characters, negative FTA and positive FTA and FSA. In Barbie as the Princess and the Pauper movie, the data shows the using of FTA talked by Princess Anneliese is 3,6\% and by Preminger is 5\%. It shows that Preminger more dominants in using FTA than Princess Anneliese. About FSA, Princess Anneliese is 3,6\% and Preminger is 6,8\%. Preminger likes to talk in FSA ways and Princess Anneliese as same as in using FTA and FSA.
\end{abstract}

Keywords: Politeness, Face Threatening Act, Face Saving Act, Barbie Movie.

\section{INTRODUCTION}

Language can be used to encourage, discourage, enhance good communication or even cause conflict between interlocutors, hence there is a needed to use polite language for better communication in daily life. Thus, the point is if language is the most important thing in social activities to tell the information through a common system of a symbol in human. Parmawati (2018) states that in the era of globalization, learning English is very important because English able for

linking and make easily people in the most of countries are communicated each other based on the development in the field of economic, business, education and also pol iticCommunication is the most important in daily life, especially for human activity and involves emotion. It is argue by Holtgrave (2008) cited in (Asiko \& Ph, 2018) explains that acts of communication are forms of social discourse which maintain and regulate social activities, and define status and power relations. In society, human beings need to corporate with other people. Therefore, human can't live alone because they depend on each other.

Pragmatics is a branch of linguistic which is a study about the aspects of meaning in a situation and other features of the context of utterance. It is related to Mey (1993: 42) cited in (Pragmatics, 2016) defines pragmatics is the study of the conditions of human language use as these are determined by the context of society. This study is focused on how people express different meaning and interpret it in different ways. Yule (1996: 3) cited in (Marpaung, n.d.) defines pragmatics is the study of speaker meaning and contextual meaning. Meanwhile, Levinson 
(1983: 24) cited in Tamunobelema (2017) in assumes that pragmatics is the study of the ability of language users to pair sentences with the contexts in which they would be appropriate. The pragmatics is the rule of human language to get a meaning, context, and interpretation in communication of social life.

From the definition above, it can be understood that pragmatics is a study about the ability of language user to interpretation what people mean in a particular context and how context influences what is said. The interpretation can be channeled through politeness, included the Face Threatening Act or Face Saving Act on communication in daily life.

Politeness is something to be owned by everyone in making conversation with using appropriate politeness in communication. According to (Leech, 2005) politeness is strategic conflict avoidance which can be measured in terms of degree of effort. It means politeness is used to avoid discomfort or not respected between the speaker and the hearer in a communication. Thomas (1995: 150) cited in (Ruansyah \& Rukmini, 2018) stated that politeness was a realworld goal (politeness interpreted as a real desire to be pleasant to others or as the underlying motivation for an individual's linguistic behavior).

Politeness theory is the theory that accounts for the redressing of the affronts to face posed by face-threatening acts to addressee. Brown and Levinson (1987) cited in (Iswara \& Saleh, 2017) formulated that, politeness theory has since expanded academia's perception of politeness. Politeness is the expression of the speakers' intention to mitigate face threats carried by certain face threatening acts toward another (Mills 2003:6) cited in (Siburian, 2016).

A Face Threatening Act (FTA) is an act which challenges the face wants of an interlocutor. According to Brown and Levinson (1987:25) cited in (Kedveš, 2013), face threatening acts may threaten either the speaker's face or the hearer's face and they may threatening either positive face or negative face. Every single thing we dare to say will affect not only our hearer's face but also our own face. Face Saving Act (FSA) refers to maintain a good self-image. People who are involved in a conflict and secretly know they are wrong will often not admit that they made a mistake. They therefore continue the conflict, just avoid the embarrassment of looking bad.

\section{Positive and negative face}

The face is the public self-image that every adult tries to project. In their 1987 book, Brown and Levinson defined the positive face two ways:

\section{Positive Face}

Refer to one's self-esteem, while the negative face refers to one's freedom to act. The two aspects of face are the basic wants in any social interaction, and so during any social interaction, cooperation is needed among the participants to maintain each other's faces.

\section{Negative face}

It is defined as "the want of every 'competent adult member' that his actions be unimpeded by others" or "the basic claim to territories, personal preserves, rights to non-distraction. The freedom of action and freedom from imposition." 


\section{Face threating act}

The person who is being stared at must wonder, what is wrong. A child (or adult) at times can be more expressive and rather than hide FTA, might express him or herself openly. Sticking one's tongue out at someone else can be done with no attempt to conceal the act. It can be a Face Threating Act 'in your face' (Leech, 1983:56) cited in (María \& Corresponding, 2012).

\section{Negative face-threatening acts}

Negative face is threatened when an individual does not avoid or intend to avoid the obstruction of their interlocutor's freedom of action.

\section{Positive face-threatening acts}

Positive face is threatened when the speaker or hearer does not care about their iterator's feelings, wants, or does not want what the other wants.

\section{Face saving act}

Face saving act people corporate (and assume each other's cooperation) in maintaining face interaction, such a cooperation being based on the mutual vulnerability of the face, Levinson(1987: 61) cited in (Culpeper, 2011).

The researchers choose Barbie as The Princess and The Pauper Movie because that movie tells about a royal's life as a theme. It can be seen clearly from the title, and all of us know that something which refers to such a royal story has a deep connection with politeness.

The researchers analyze this movie because of their story is interesting. It tells there was a princess named Princess Anneliese. Apparently she was unhappy and wanted to be free from the confines of a princess's life so binding. Meanwhile, Erica, an ordinary girl who wants to escape from poverty and her position as a servant of a cruel employer, Madame Carp. One day they accidentally met and surprised them. They are so similar to each other like twins only.

Shortly after Princess Anneliese was kidnapped by a group of Preminger's right hand men. It turned out that the kidnapping was masterminded by the evil adviser of the Queen, Preminger. Preminger did that in order to influence Queen and smooth his plans to become king. Erika's dream of becoming a rich woman was fulfilled when Julian, mentor of Princess Anneliese asked her to impersonate the Princess.

Julian, who secretly loved Princess Anneliese that in order to get time to discover who the mastermind of the Princess's abduction. Meanwhile, Erica really enjoyed the life of a Princess while trying to save Princess Anneliese. But the problem becomes complicated when Erica met a handsome King named Dominick. Apparently King Dominick fell in love with Erica, who he thought was Princess Anneliese. Instead, Erica was in love with King Dominick but did not dare to tell the truth who she really is.

From that story we could know that Princess Anneliese had a wonderful life in the beginning of the story. The usage of Face Threating Act and Face Saving Act on Princess Annaliese appeared in many times in her life. But other characters also apply Face Threating Act and Face Saving Act too. But the researchers only analyze the use of Face Threating Act and Face Saving Act that used by Princess Annaliese and Preminger. 
From the description on the background above, it is considered very necessary to do action research to solve the problems, like (1) What are the types of Face threatening Act or Face Saving Act used by the characters in the movie? (2) What are the functions of each Facethreatening Act or Face Saving Act which are used by the characters in the movie? (3) What the context do the characters use a Face threatening Act or Face Saving Act for politeness strategy? The results of this study are expected to provide practical and theoretical benefit for life and linguistic development in general and pragmatics in particular.

\section{METHOD}

This research is classified as a descriptive qualitative method because the data of this research are in the form of utterances and words. This research supported by percentage calculation with the formula $\frac{n}{\text { maximum number }} \times 100=\cdots \%$ to count percentage Princess Anneliese and Preminger using Politeness in Barbie as the princess and the pauper. Arikunto (1993:8) cited in (Siburian, 2016) states that the research methods are method used by researchers to collecting the data research. In line with Berg (1989:2) cited in (Subjects, 2018), a qualitative research is a type of research which tries to describe an object. Besides that, the descriptive qualitative method is used because the aims of this research are to describe and to explain the types and functions of Face Threatening Act uses in relation with politeness in the conversation by Princess Annaliese and Preminger in Barbie as The Princess and The Pauper movie. The oral utterances that appeared in the movie were analyzing and interpret descriptively based on Brown and Levinson's Face Threatening Acts theory.

In this research, the data are gathered from the utterances or words in the conversations by Princess Annaliese and Preminger in Barbie as The Princess and The Pauper movie. The technique that is used for this research is Non-Participant Observation Technique. NonParticipant Observation is a research technique whereby the researchers watches the subjects of his/her study, with their knowledge, but without taking an active part in the situation. It is a simple method to use because the data are collected by observing behavior without interacting with the participant. Thus, it is easier for the researcher to record data promptly and objectively, like a movie, as one of the examples. Data collection can be derived from a number of methods, which include interviews, focus groups, surveys, telephone interviews, field notes, taped social interaction or questionnaires (Heaton, 2004:37) cited in (Andrews, Higgins, Andrews, \& Lalor, 2012). To collect the data, the researcher uses two steps:

(1) Collecting the conversation of Princess Annaliese and Preminger in Barbie as The Princess and The Pauper movie by watching the movie and listening the conversations carefully in order to get deep understanding about the topic.

(2) Because this research intends to qualitative study, in collecting the data, the researcher applies fields note or documentation. Then, the researcher selects the data obtained from data sources to meet the nature of the problems of the study.

After the data collected, the researchers integrated and related the the data to the background of the study, mainly to the research questions, theories, and the methodology for classifying the data into manageable units as proposed by Emilia (2008, cited in Apsari, 2018).

\section{RESULTS AND DISCUSSION}

\section{Results}


The researchers found more than one the use of Face threatening Act and Face Saving Act that used by Princess Anneliese and Preminger in Barbie as The Princess and The Pauper Movie. Here are what researchers found.

\section{FTA (Face Threatening Act)}

The Princess Anneliese said:

1. "I command you that unlock the door"

2. "You are speaking with Princess Annaliese, let me in!", "How dare you speak to her that way"

3. "I'm warning you, if your treat your tailor this way, we will take our royal business end"

4. "Stop the wedding mother"

Preminger said:

1. "Making a decision without me? Who does she think she is?"

2. "Well this is dreadful"

3. "Turn around! Stop, you stupid beast! I said stop!

\section{FSA (Face Saving Act)}

The Princess Anneliese said:

1. "I don't understand Preminger, why do you do this?"

2. "How would you to be king?"

3. "I beg your pardon"

4. "You are behind this!"

Preminger said:

1. "A most wise and thoughtful decision, Your Majesty?"

2. "Why don't you stick to your book, Schoolboy"

3. "Very clever planting a double to fool even me. But not quite clever enough"

4. "I only just discovered the truth myself, Your Majesty"

\begin{tabular}{clclc}
\hline No. & \multicolumn{1}{c}{ Speaker } & Types of Politeness & \multicolumn{1}{c}{ Quantity } & Percentage \\
\hline 1 & Princess Anneliese & Negative \& Possitive FTA & 4 from 112 & $3,6 \%$ \\
2 & Preminger & Negative \& Possitive FTA & 3 from 59 & $5 \%$ \\
3 & Princess Anneliese & FSA & 4 from 112 & $3,6 \%$ \\
4 & Preminger & FSA & 4 from 59 & $6,8 \%$ \\
\hline
\end{tabular}

\section{Discussion}

Based on their sentences, they used Face threatening Act based on Brown and Levinson's theory. In Barbie as the Princess and the Pauper, Princess Anneliese talked about 112 times and a couple dialogs used positive and negative Face Threatening Act in many times. Which is implemented because The Princess Anneliese wants to be respected by all people because she is a Princess. The context when she uses those sentences:

1. When she looked at small room, kidnapped by Preminger's right hand men, she commands that because she is a princess and wants to be free. From Princess Anneliese utterances, she used negative Face Threatening Act in order to be free from the small room. 
2. When she talked with her guide, she used negative Face Threatening Act, because her guide didn't know if she is a princess. At this moment Princess Annaliese succeeding escaped from Preminger's right-hand men and she went back home but, the guide don't let her in, the guide thought Princess Anneliese was lying. Because Erica was there pretending to be Princess Anneliese inside The castle.

3. Princess Annaliese talked with Mrs. Carp, as an owner who joined with Royal family. Mrs. Carp thought that Princess Annaliese was Erica, the woman who worked at her boutique. Actually, Erica and Princess Annaliese look alike. Unfortunately, Mrs. Carp did not believe it and order another employee in a disrespectful way. Then, Princess Anneliese got angry to Mrs. Carp and said using negative Face Threatening Act so that Mrs.Carp getting respect to Princess Anneliese and to Mrs.Carp employee, but she didn't pay attention about that.

4. In this way Princess Anneliese used positive Face Threatening Act in order to save her mother from an awful wedding. So that her mother did not marry with Preminger, because Preminger just wanted to be King with powerful force without loving people and the Queen.

The data shows Princess Anneliese using negative and positive Face threating Act only 3,6\%. Most the way in the dialog, she talked wisely and clearly without giving any threated.

The usage of Preminger Face Threatening Act based on Brown and Levinson's theory. They used positive Face Threating Act in many times. Which is implemented because The Preminger always lying to the Queen a King Dominick. The context, when he uses those sentences as, follows:

1. In context to against Queen's decision, Preminger said using negative Face Threating Act. Preminger is the one who wants to take the reign off from Queen's hand got shock when he heard that the Queen decided to marry her off to the King of Dulcenia next week. If the Princess Anneliese marries with the King of Dulcenia then he never be king.

2. Preminger said she was run way and she won't marry with King Dominick. But it's all were fake, Preminger arranged this lying. In this situation Preminger used Face Threatening Act, in context to have a mercy to the Queen.

3. When Preminger runs away from the guides of the kingdom, he rides his horse but his horse take a wrong way because the horse stands with the Queen. Preminger said like that way and hit the horse to get back into the right way to escape from the Castle. But the horse still chooses a way to get back to the castle, after arriving in the castle toss Preminger into the guides.

Thus, there are some briefly explanation to answer the question, Preminger used 5\% from 59 times she talked in the dialog. Most the way he talked with anger.

Face Saving Act also needed in daily conversation, it is needed because we should to maintain the face of the hearer. Here are the explanation about Princess Anneliese Face Saving act:

1. Princess Anneliese was at the Gold Mining, kidnapping by Preminger and Preminger's right hand man. She felt confuse about this all. In this situation Princess Anneliese used Face Saving Act because she didn't know what exactly happen there.

2. Using Face Saving Act, at the inside gold mining, Princess Anneliese asked to Preminger like that. Talked with wise intonation showing that she is a princess. But, at the same time she knows Preminger's bad idea about what he is going to do with her mom or as known as Queen. 
3. Talked to Preminger inside the gold mining, she said like that way because she wants to be free. She begged her pardon, but Preminger had no heart and didn't listen and even don't care about the Princess Anneliese, so she uses Face Saving act at this moment to attract Preminger but it was no succeeded.

4. Using Face Saving Act, Princess Anneliese talked wisely and classy intonation shows that she was the real princess, she said to her mother and people if Preminger behind these all. From the kidnapped the Princess and all the drama that happened during a couple days.

Princess Anneliese used Face Saving Act in order to maintain the face of the hearer 3,6\% from 112 times she talked in the movie.

The usage of Preminger Face Saving Act based on Brown and Levinson's theory. They used Face Saving Act in many times. Which is implemented because The Preminger wants to be a King and marry with The Queen and he always told to Princess Anneliese, the Queen and other members of the kingdom as like a good person but he always lying. The context, when he used those sentences as, follows:

1. In this moment, Ambassador of Duclenia, Julian and the Queen suddenly saw Preminger when he said 'Ah, next week.' He saved him and said 'A most wise and thoughtful decision, Your Majesty.' Preminger used Face Saving Act in order to make the situation still conducive, and everyone didn't get suspicious to him.

2. Preminger didn't want to be helped by Julian when he offers him help. Because Preminger wants to have good image but he felt annoyed about Julian word, Preminger takes Face Saving Act Action in Thar situation.

3. Preminger was angry and happy to know the mystery that happened. He used Face Saving Act to Princess Anneliese and Julian in Gold Mining after knew that Julian made the other Princess Anneliese as known as Erica. He felt like no one could fool him off. After knowing the truth Preminger feeling so happy then he could run his plan.

4. The Queen feels very confused about what happened to her daughter. Because Preminger said 'she is a fake and common pauper.' After discovering mystery in a couple days Preminger found that the Princess in the castle at that time was not the real Princess Anneliese but she is Erica who looks alike. In this context Preminger used the Face Saving Act to show that he can found the truth to the Queen.

About 6,7\% Preminger talked with Face Saving Act, in this context Preminger just pretending to be kind so he talked with Face Saving Act. There are some briefly explanation about Face Saving act that used by Princess Anneliese that we found in the Barbie as the Princess and The Pauper.

\section{CONCLUSION}

The conclusion of this research can be formulated based on the proposed research question. So there are so many sentences that the Princess Anneliese and Preminger said using Face Threatening Act and Face Saving Act, and the researchers already gave explanation about those all. It can be concluded that the researchers found the using of negative-positive Face Threatening Act (FTA) and Face Saving Act (FSA) used by Princess Anneliese and Preminger in Barbie as The Princess and The Pauper Movie. 
In the main character is Princess Anneliese, there are two politeness, FTA and FSA. In the Face Threatening Act, there is 3,6\% that used by Princess Anneliese, it is included three negative and one positive FTA. However, in the Face Saving Act, there are 3,6\% that used by Princess Anneliese, it tells us that the use of FTA and FSA in Princess Anneliese dialog is balance. About Preminger, there are two politeness, FTA and FSA. In the Face Threatening Act, there is 5\% that used by Preminger, it is included three negative and one positive FTA. But, in the Face Saving Act there are 6,8\% that used by Preminger, shows that Preminger used FTA and FSA more than Princess Anneliese.

By looking at this analysis, it hoped that we can learn how to implement the FTA and FSA in daily life, because FTA and FSA are very important in order to create a comfortable interaction with each other. In addition, it is also recommended for the next researchers who are interested in doing further research in this area to use these finding as a starting point in conducting the research. Using the same theory of Brown and Levinson \& Yule, the next researchers are suggested to use different data sources, in this case daily conversation which can be formal or informal dialogue or in any literary work. To make this journal more perfectly, the criticism and suggestion from the readers are needed.

\section{ACKNOWLEDGMENTS}

Thank god who has given the researchers his love and compassion to finish with good condition the journal entitled: Analysis About Politeness In Barbie as The Princess and The Pauper Movie. This journal is the requirement for accomplishing S-1 degree in English Education Department IKIP Siliwangi, Cimahi.

The researchers greatest appreciation also to Mr. Yana, S.Pd, M.Hum. as The Head of English Education Study Program. We also want to deliver our sincere thank to our adviser Mrs. Ula Niza El Fuziah, S.Pd, M.Hum. who always gave researchers support when conducting this research. We also thank you to all lecturers in English Education Study Program for all your time to share your knowledge or anything is more important to us in pursuing this project and the members of our family. We would like to say thank you to our parents for their endless love in giving us support morally, motivation, and material support.

\section{REFERENCES}

Andrews, L., Higgins, A., Andrews, M. W., \& Lalor, J. G. (2012). Classic Grounded Theory to Analyse Secondary Data : Reality and Reflections, 11(1), 12-26.

Apsari, Y. (2018). Reflective Reading Journal In Teaching Writing. Indonesian Efl Journal, 4(2), 39-47.

Asiko, B., \& Ph, A. (2018). Politeness as an Art in Communication : The 2016 USA Presidential Campaign Poster $\mathfrak{a}^{\mathrm{TM}}$ s Slogans, 5(1).

Culpeper, J. (2011). Politeness and Impoliteness, 5, 1-41.

Iswara, R. W., \& Saleh, M. (2017). FTA and Politeness Strategies in Prospective Students ' Personal Statements to Apply for A Master's Program Abroad, 7(2), 156-163.

Kedveš, A. (2013). Face threatening acts and politeness strategies in summer school application calls, 3, 431-444.

Leech, G. (2005). Politeness : Is there an East-West Divide ? (1), (6).

María, J., \& Corresponding, G. (2012). Face-Threatening Speech Acts and Face-Invading Speech Acts : An Interpretation of Politeness Phenomena, 4(2), 400-411. https://doi.org/10.5296/ijl.v4i2.1858 
Marpaung, Y. (n.d.). A Pragmatic study of Graffiti on Public Transportations in Medan.

Parmawati, A. (2018). Using Analytic Teams Technique To Improve Students'speaking Skill.

Edulitics (Education, Literature, And Linguistics) Journal, 3(2), 21-25.

Pragmatics, W. I. S. (2016). A highlight on pragmatics, 16(1), 83-92.

Ruansyah, R. A., \& Rukmini, D. (2018). The Host 's Politeness Strategies in Ellen Degeneres Reality Talk Show, 8(1), 96-106.

Siburian, A. (2016). An Analysis Of Politeness Strategy In Soimah Talkshow In TRANS TV, $2(3), 1-13$.

Subjects, R. (2018). Mp r a, (85654). 